\title{
From Warfare to Welfare - Human Security in a Southern African Context
}

\author{
Marie Muller and Bas de Gaay Fortman (eds.)
}

Assen: Royal van Gorcum, 2004

118 pages

Figures (11)

ISBN $\quad \mathrm{Pb} 902324043 \mathrm{X}$

Price unknown

It is encouraging to find a valuable contribution to the understanding of the complexities of human security and how it can be integrated with development programmes. This edited book of 118 pages contains an introduction by Marie Muller, one of the editors, and eight chapters with no glossary or index. Each chapter ends with a list of references. The book is the result of a series of conferences between the South African and Netherlands Pugwash groups. It is divided into two parts, the first, conceptual and general, comprises four chapters, while the latter four 'praxis' chapters being more applicable to the Southern African policy and governance context.

The book sets out to establish an integrated development approach towards the plethora of insecurity factors facing countless African people. Chapter 1 by Bas de Gaay Fortman (The golden triangle of human dignity: Human security, human development and human rights) attempts to establish a link between democratisation and development by positing a relationship between human development, human security and human rights. The link between human security and human rights in countries scoring low on the human development index (HDI) is illustrated. The security-development link is discussed by reference to economic factors while the security-rights link is informed with reference to four elements of conflict transformation. Other factors receiving attention include the rule of law, the role of strong individuals and civil society, institutions, leadership and education.

Chapter 2 by Sverre Lodgaard (Human security: Concept and Operation) is divided into two parts, the one conceptual, the other operational. The conceptual part gives the reader clarification on concepts such as state security, human security, 
adjustment to systemic change, widening and consolidation, securitisation and desecuritisation and the setting of an agenda. The operational part looks at policies, preventive action, small arms, peace operations for human security, financial constraints and political constraints. Lodgaard points out that the state no longer monopolises the concept of security but that its referent objects of 'state' and 'people' has been expanded to include 'society' and 'eco-system'. Thus, survival now requires the protection of sovereignty and identity. Human security means the provision of a 'sense of security', of freedom from structural and direct violence. Eight categories of crisis prevention are discussed. The chapter is concluded with a look at the use of small arms in criminality and armed conflict.

Chapter 3 by Marion Kappeyne van de Copello (Intrastate conflicts and development policy orientations: A call for a concerted strategy) points out that conflict, violence and development are interconnected - that conflict is inherently part of political, social and economic processes of change. The three stages of conflict require three different kinds of policy responses: tension requires prevention, violence requires mitigation, and resolution requires peace building. Van de Copello mentions a number of underlying causes of conflict and that early warning is more than adequate. What is currently lacking is international attention or response to early warning. Two related problems with prevention are that it seems uninteresting and that state sovereignty discourages timely response. Different mechanisms of action during conflict are discussed. The multidimensional nature of post-conflict peace building is also described with emphasis on the importance of security sector reform. The author indicates that imposed democracy seldom succeeds. Conflict results from unfulfilled needs that can only be addressed through governance institutions and processes, the "core of democracy". Thus a comprehensive, integrated approach is needed to deal with complex intrastate or intraregional violent conflict.

Chapter 4 by Sylvia Borren (Mind the gap: An agenda for Africa) contemplates the gap between the millennium development goals for 2015 and the slow progress actually made in Africa. Borren demonstrates how little it would cost to bridge the gap, e.g. 3\% of expenditure on subsidized agriculture in developed countries (US \$8 bn) is what is needed per year to put every child in the world through proper education. In all three 'spheres of influence', the market, the state, and civil society, 'ethical globalists' are asking for corporate responsibility, peopleoriented politics and transparent and accountable civil-society. Some of the optimistic signs of transformation are mentioned, but progress at the global level needs to speed up, e.g. the Bretton Woods architecture, the intellectual property rights regime, subsidized product dumping, tariff barriers, etc. 
Chapter 5 by Maxi Schoeman (Developing an integrated approach to human security in Southern Africa) describes the new security agenda and asks who is responsible for this 'new' security. The chapter investigates the link between security and development and provides an integrated approach to the challenge of providing both development and security in Southern Africa. In the first section the security-development nexus is analysed by means of critical theory that emphasises equity, justice, freedom and emancipation. Goulet's three core values of development, sustenance, self-esteem, and freedom from servitude indicate the integration of political, social economic and cultural factors required to ensure human development in its full context. In the second section the challenges and problems facing the Southern African Development Community (SADC) in promoting security and development are discussed. On the one hand there is a lack of political will, on the other hand notions of the state, sovereignty and national interests obstruct the practical issues of implementing SADC protocols. From a human security perspective both the state and the region (SADC) need to get their house in order when considering the following words by Schoeman (2004:71): "The first and ultimate test of security, seen from a critical perspective, is to achieve a moral and just society in which people are the main actors, referents and agents of security".

Chapter 6 by Hussein Solomon (The Southern African Development Community: Regional imperatives and donor assistance) gives a brief historical overview of SADC and identifies areas of weakness where the international donor community can assist the organisation and the region's people. SADC security dimensions are discussed together with shortcomings and recommendations. This is followed by an exploration of what the international community can do towards a peaceful and secure SADC by looking at existing initiatives and an enhancement of the role of NGOs. The last part of the chapter looks at the economic and development dimensions in SADC, more specifically demographics, economics, environmental, and global political economy factors. Once again the role the international community can play in sustainable development in Southern Africa is highlighted.

In Chapter 7 (Law and the state: Limitations to human security) Lala Camerer discusses crime, corruption and organised crime in terms of the threat they pose to patterns of daily life, especially given the limited capacity of the state and its legislation and judicial systems to address these symptoms of human insecurity. Crime and corruption affect citizens' views of state legitimacy negatively and become both cause and consequence of underdevelopment and poverty. The Public Anti-Corruption Strategy and other national and international anti-corruption events are mentioned. Camerer iterates that the South African Government's will to 
address corruption is being seriously tested by the new business and political elite, especially where new procurement deals are concerned. Seven factors facilitating the growth of international organised crime in South Africa are also discussed. The conclusion is drawn that good governance and state capacity are critically important in providing a judicial state with effective bureaucracy that can ensure human security. Camerer correctly points out that the locus of responsibility for citizen welfare and liberty as well as conflict management when not exercised by society, remain with the state.

Chapter 8 by Jakkie Cilliers (Stability and security in Southern Africa) provides and overview of the state of the nation in Southern Africa, as well as an update and cursory analysis of formal security relationships in Southern Africa. On the positive side Cilliers refers to the "end to armed conflict" in Angola, the Democratic Republic of the Congo, Lesotho and Mozambique. On the negative side the reader is reminded of food insecurity, HIV/AIDS, political repression and abuse of power, all of which continue to contribute to state collapse in the region. The impact of colonialism on the state and the "ultra political" nature of the postindependent state are described. Cilliers also focuses on the post-1950 Southern African state history, the establishment of SADC, fruitless efforts to bring an Association of Southern African States (ASAS) into being, and the establishment of the Organ on Politics Defence and Security Co-operation (OPDS) with its Inter-state Defence and Security Committee (ISDSC) and Inter-state Politics and Diplomacy Committee (ISPDC). The chapter is concluded with a look at the Southern African Regional Police Chiefs Co-operation Organisation (SARPCCO).

This book is important for two reasons. Firstly, it highlights clearly the lack of human security in Southern Africa by providing the reader with a number of conceptual tools to adequately understand the extent of the crisis. Secondly, it provides a basic framework that indicates the integrated action that is required from multiple role-players, especially the state and bureaucracy, to establish and maintain human security. The book can be criticized for not adequately addressing certain issues. The chapter on "Law and the state" by Camerer is just longer than seven pages and does not reflect adequately the dire impact of crime and lawlessness on many communities and individuals in Southern Africa. What is further lacking is the issue of addressing human security at the micro level - that of the individual and family and the responsibility of local authorities in this regard. Theoretically it is not quite clear what message the book as a whole portrays, perhaps the result of being a compilation of nine people's work. The chapter by Schoeman clearly pronounces a critical theoretical perspective where the emphasis is on people as the "main actors, referents and agents of security". However the other three praxis chapters by Solomon, Camerer and Cilliers focus almost exclusively on the state and 
supranational organisations such as SADC as the provider/s of security. Perhaps this is indicative of the nature of the so-called 'new security agenda' that academics, politicians, NGOs and ordinary people are trying to come to grips with.

From Warfare to Welfare is an accessible and very readable book that would be suitable as a supplementary text in any graduate course in International Relations, African Politics or Development Studies. It would be equally at home in a Contemporary History or Applied Sociology class and should probably be required reading in any course dealing with Southern African politics, security or development.

Lt Col Inus du Plessis, Centre for Military Studies (Gauteng branch), Stellenbosch University 